\title{
PENGARUH LINGKUNGAN TEMAN SEBAYA, LINGKUNGAN KELUARGA, DAN MOTIVASI BELAJAR TERHADAP PRESTASI BELAJAR AKUNTANSI SISWA KELAS XII IPS SMA NEGERI 1 SEWON TAHUN AJARAN 2018/2019
}

\author{
THE EFFECT OF NEIGHBORHOOD PEER, FAMILY ENVIRONMENT, AND \\ LEARNING MOTIVATION TOWARD ACHIEVEMENT OF ACCOUNTING IN CLASS \\ XII SOCIAL SMA NEGERI 1 SEWON ACADEMIC YEAR 2018/2019
}

Oleh:

Fitri Asoka Wati

Prodi Pendidikan Akuntansi Universitas Negeri Yogyakarta

Fitriasoka82@gmail.com

Isroah

Staf Pengajar Jurusan Pendidikan Akuntansi Universitas Negeri Yogyakarta

\begin{abstract}
Abstrak
Penelitian ini bertujuan untuk mengetahui: 1) Pengaruh Lingkungan Teman Sebaya terhadap Prestasi Belajar Akuntansi Siswa Kelas XII IPS SMA N 1 Sewon Tahun Ajaran 2018/2019. 2) Pengaruh Lingkungan Keluarga terhadap Prestasi Belajar Akuntansi Siswa Kelas XII IPS SMA N 1 Sewon Tahun Ajaran 2018/2019. 3) Pengaruh Motivasi Belajar terhadap Prestasi Belajar Akuntansi Siswa Kelas XII IPS SMA N 1 Sewon Tahun Ajaran 2018/2019, dan 4) Pengaruh Lingkungan Teman Sebaya, Lingkungan Keluarga, dan Motivasi Belajar secara bersama-sama terhadap Prestasi Belajar Akuntansi Siswa Kelas XII IPS SMA N 1 Sewon Tahun Ajaran 2018/2019. Penelitian ini merupakan penelitian ex post facto. Teknik pengumpulan data yang digunakan adalah angket dan dokumentasi. Populasi dari penelitian ini adalah seluruh Siswa Kelas XII IPS SMA Negeri 1 Sewon Tahun Ajaran 2018/2019, yaitu 107 siswa. Teknik pengambilan sampel dalam penelitian ini adalah Proportionate Stratified Random Sampling, yaitu sejumlah 83 siswa. Uji prasyarat analisis yang digunakan adalah uji normalitas, uji linieritas, dan uji multikolinearitas. Teknik analisis data yang digunakan yaitu analisis regresi sederhana dan analisis regresi ganda. Hasil penelitian ini adalah: 1) Terdapat pengaruh positif dan signifikan Lingkungan Teman Sebaya terhadap Prestasi Belajar Akuntansi Siswa Kelas XII IPS SMA N 1 Sewon Tahun Ajaran 2018/2019 dengan nilai $r_{x 1 y} 0,423 ; r_{x 1 y}^{2} 0,179 ; t_{\text {hitung }} 4,200>$ $\mathrm{t}_{\text {tabel }} 1$,664. 2) Terdapat pengaruh positif dan signifikan Lingkungan Keluarga terhadap Prestasi Belajar Akuntansi Siswa Kelas XII IPS SMA N 1 Sewon Tahun Ajaran 2018/2019 dengan nilai $\mathrm{r}_{\mathrm{x} 2 \mathrm{y}}$ 0,354; $\mathrm{r}^{2}{ }_{\mathrm{x} 2 \mathrm{y}} 0,125$; $\mathrm{t}_{\text {hitung }} 3,406>\mathrm{t}_{\text {tabel }} 1,664$. 3) Terdapat pengaruh positif dan signifikan Motivasi Belajar terhadap Prestasi Belajar Akuntansi Siswa Kelas XII IPS SMA N 1 Sewon Tahun Ajaran 2018/2019 dengan nilai $\mathrm{r}_{\mathrm{x} 3 \mathrm{y}} 0,396 ; \mathrm{r}^{2} \times 3 \mathrm{y} 0,157 ; \mathrm{t}_{\text {hitung }} 3,884>\mathrm{t}_{\text {tabel }} 1,664$. 4) Terdapat pengaruh positif dan signifikan Lingkungan Teman Sebaya, Lingkungan Keluarga, dan Motivasi Belajar secara bersamasama terhadap Prestasi Belajar Akuntansi Siswa Kelas XII IPS SMA N 1 Sewon Tahun Ajaran $2018 / 2019$ dengan nilai $R_{y(1,2,3)} 0,443 ; R_{y(1,2,3)}^{2} 0,196 ; F_{\text {hitung }} 6,432>F_{\text {tabel }} 2,72$.
\end{abstract}

Kata kunci: Lingkungan Teman Sebaya, Lingkungan Keluarga, Motivasi Belajar, Prestasi Belajar Akuntansi

\section{Abstract}

This research aims to determine: 1) Effect of Neighborhood Peer toward Achievement of Accounting in class XII Social SMA Negeri 1 Sewon academic year 2018/2019, 2) Effect of Family Environment toward Achievement of Accounting in class XII Social SMA Negeri 1 Sewon academic 
year 2018/2019, 3) Effect of Learning Motivation toward Achievement of Accounting in class XII Social SMA Negeri 1 Sewon academic year 2018/2019, 4) Effect of Neighborhood Peer, Family Environment, and Learning Motivation toward Achievement of Accounting in class XII Social SMA Negeri 1 Sewon Academic Year 2018/2019. The type of this research was ex post facto. Data collection techniques used are questionnaires and documentation. The population of this study were all students of class XII Social SMA Negeri 1 Sewon Academic Year 2018/2019, namely 107 students. The sampling technique in this study is the Proportionate Stratified Random Sampling, which is 83 students Test analysis conducted prerequisite is normality test, linearity test, and multicollinearity test. The analysis technique used is simple regression analysis and multiple regression. The result of this are: 1) There is a positive and significant Neighborhood Peer toward Achievement of Accounting class XII Social SMA Negeri 1 Sewon Academic Year 2018/2019 with a value $r_{x I y} 0,423 ; r_{x I y}^{2} 0,179$; $t_{\text {hitung }} 4,200>t_{\text {tabel }}$ 1,664. 2) There is a positive and significant Family Environment toward Achievement of Accounting class XII Social SMA Negeri 1 Sewon Academic Year 2018/2019 with a value $r_{x 2 y} 0,354 ; r_{x 2 y}^{2} 0,125$; $\left.t_{\text {hitung }} 3,406>t_{\text {tabel }} 1,664,3\right)$ There is a positive and significant Learning Motivation toward Achievement of Accounting class XII Social SMA Negeri 1 Sewon Academic Year 2018/2019 with a value $\left.r_{x 3 y} 0,396 ; r_{x 3 y}^{2} 0,157 ; t_{\text {hitung }} 3,884>t_{\text {tabel }} 1,664,4\right)$ There is a positive and significant Neighborhood Peer, Family Environment, and Learning Motivation together toward Achievement of Accounting class XII Social SMA Negeri 1 Sewon Academic Year 2018/2019 with a value $R_{y(1,2,3)} 0,443 ; R_{y(1,2,3)}^{2} 0,196 ; F_{\text {hitung }} 6,432>F_{\text {tabel }} 2,72$.

Keywords: Neighborhood Peer, Family Environment, Learning Motivation, Avhievement of Accounting

\section{PENDAHULUAN}

Pendidikan merupakan salah satu aspek kehidupan yang akan melahirkan generasi-generasi penerus bangsa. Generasi-generasi penerus bangsa ini yang nantinya akan membawa Indonesia ke arah pembaharuan. Pendidikan di Indonesia mengalami perbaikan dari waktu ke waktu dalam berbagai sisi, antara lain pada metode pembelajaran, kurikulum, program sertifikasi, peningkatan standar kelulusan, program-program yang diberikan untuk menunjang kesejahteraan guru, dsb. Perbaikan ini dilakukan karena pendidikan tidak hanya dituntut untuk melahirkan generasi penerus yang cerdas namun lebih dari itu. "Pendidikan itu sendiri memiliki definisi, yaitu suatu usaha yang dilakukan secara sadar dan sengaja untuk mengubah tingkah laku manusia baik secara individu maupun kelompok untuk mendewasakan manusia melalui upaya pengajaran dan pelatihan" (Sugihartono, 2015: 3).

Keberhasilan pendidikan dapat diketahui melalui kenaikan maupun penurunan kualitas pendidikan. Kualitas pendidikan ini tidak jauh kaitannya dengan proses belajar mengajar, kinerja pendidik, kurikulum, fasilitas pendidikan, manajemen organisasi pendidikannya, dan peserta didik atau siswa itu sendiri. Peserta didik atau siswa memiliki kaitan dengan kualitas pendidikan karena peserta didik merupakan objek dari pendidikan. Peserta didik di sini berasal dari Sekolah Dasar (SD), Sekolah Menengah Pertama (SMP), Sekolah Menengah Atas (SMA), dan Perguruan Tinggi baik Perguruan Tinggi Negeri (PTN) atau Perguruan Tinggi Swasta (PTS).

Kualitas pendidikan di sini merupakan suatu aspek yang sangat diperhatikan oleh pemerintah. Pemerintah selalu mengkaji ulang mengenai kebijakan yang diterapkan pada aspek pendidikan. Hal ini bertujuan agar kualitas pendidikan di Indonesia dapat selalu meningkat dari waktu ke waktu. Pemerataan pendidikan dari pedesaan hingga perkotaan, dari pulau Jawa hingga pulau terluar di Indonesia dilakukan untuk meningkatkan kualitas pendidikan. Kualitas pendidikan yang baik ini salah satunya dapat dilihat dari prestasi belajar yang didapat oleh para siswanya. 
Sekolah Menengah Atas merupakan batas minimal yang ditentukan pemerintah untuk ditempuh peserta didik yaitu melalui kebijakan Wajib Belajar 12 Tahun. Undang-Undang No. 20 tahun 2003 tentang Sistem Pendidikan Nasional Pasal 18 menyebutkan bahwa:

1) Pendidikan menengah merupakan lanjutan Pendidikan dasar,

2) Pendidikan menengah terdiri atas Pendidikan menengah umum dan Pendidikan menengah kejuruan,

3) Pendidikan menengah berbentuk sekolah mengah atas (SMA), madrasah Aliyah (MA), Sekolah Menengah Kejuruan (SMK), madrasah Aliyah kejuruan (MAK), atau bentuk lain yang sederajat.

Sekolah Menangah Atas (SMA) sederajat melaksanakan kegiatannya untuk membekali peserta didik dengan kompetensi-kompetensi yang telah ditentukan, akan tetapi terdapat beberapa masalah dalam proses pembelajaran sehingga kompetensi yang diberikan belum optimal. Hal ini menyebabkan masih kurangnya lulusan dari Sekolah Menengah Atas (SMA) sederajat yang siap menjadi tenaga kerja terlatih dan mampu bersaing memasuki bangku Perguruan Tinggi. Penyebab dari permasalahan ini tidak lepas dari peserta didik itu sendiri yang belum mendapatkan prestasi belajar yang optimal.

Faktor-faktor yang dapat mempengaruhi prestasi belajar pun memiliki banyak macam. Menurut Deni Febrini (2017: 86-98) faktor-faktor yang mempengaruhi prestasi dibagi menjadi tujuh yaitu faktor lingkungan (lingkungan alami dan lingkungan sosial budaya), faktor instrumental (kurikulum, program, sarana dan fasilitas, guru, kondisi fisiologis, dan kondisi psikologis), minat, kecerdasan, bakat, motivasi, dan kemampuan kognitif (persepsi, mengingat, dan berpikir). Menurut Slameto (2015: 54) "faktor-faktor yang mempengaruhi prestasi belajar banyak jenisnya, tetapi dapat digolongkan menjadi dua yaitu faktor intern dan faktor ekstern". Faktor-faktor belajar tersebut juga dapat mempengaruhi Prestasi Belajar Akuntansi. Faktor dari internal atau dari dalam diri siswa meliputi kesehatan, intelegensi, bakat, minat, motivasi, dan cara belajar. Sedangkan faktor eksternal atau dari luar diri siswa meliputi keluarga, sekolah, teman sebaya, masyarakat, dan lingkungan sekitar.

SMA N 1 Sewon merupakan salah satu Sekolah Menengah Atas (SMA) yang berada di Kabupaten Bantul Propinsi Daerah Istimewa Yogyakarta yang beralamat di Jalan Parangtritis km 5, Bangunharjo, Sewon, Bantul. SMA N 1 Sewon ini memiliki visi yaitu "Berprestasi Berkarakter Berbudaya dan Religius". Berdasarkan informasi yang didapatkan peneliti dari bagian tata usaha pada hari Senin tanggal 26 November 2018 di SMA Negeri 1 Sewon terdapat 107 siswa di kelas XII Jurusan IPS yang terbagi menjadi 4 kelas.

Berdasarkan dari hasil wawancara dengan guru Akuntansi SMA Negeri 1 Sewon dan dokumentasi diketahui bahwa rata-rata hasil Ulangan Harian, Penilaian Tengah Semester (PTS), dan Penilaian Akhir Semester dari 107 siswa kelas XII IPS terdapat $52,34 \%$ belum mencapai Kriteria Ketuntasan Minimal (KKM) yaitu 67. Hal ini menunjukkan Prestasi Belajar Akuntansi Siswa Kelas XII IPS SMA Negeri 1 Sewon masih banyak yang belum mencapai KKM. Menurut Direktorat Jenderal Peningkatan Mutu Pendidik dan Tenaga Kependidikan tahun 2008 tentang Kriteria dan Indikator Keberhasilan Pembelajaran, menyatakan kriteria keberhasilan pembelajaran adalah:
1) Keberhasilan peserta didik menyelesaikan serangkaian tes, baik tes formatif, tes sumatif, maupun tes keterampilan yang mencapai tingkat keberhasilan rata-rata $60 \%$.
2) Setiap keberhasilan tersebut dihubungkan dengan standar 
kompetensi dan kompetensi dasar yang ditetapkan oleh kurikulum, tingkat ketercapaian kompetensi inti ideal $75 \%$.

3) Ketercapaian keterampilan vokasional atau praktik bergantung pada tingkat resiko dan tingkat kesulitan, ditetapkan idealnya sebesar $75 \%$.

Faktor eksternal yang dapat mempengaruhi Prestasi Belajar Akuntansi siswa SMA Negeri 1 Sewon diantaranya adalah Lingkungan Teman Sebaya, Lingkungan Keluarga, dan Metode Mengajar Guru. Faktor internal yang mempengaruhi Prestasi Belajar Akuntansi siswa diantaranya adalah Motivasi Belajar.

Lingkungan Teman Sebaya merupakan lingkungan yang paling sering berinteraksi dengan siswa di sekolah. Siswa akan bersosialisasi dengan siswa lainnya pada Lingkungan Teman Sebaya tersebut. Lingkungan Teman Sebaya ini dapat memberikan dampak positif maupun negatif kepada siswa. Lingkungan Teman Sebaya yang memberikan dampak positif berakibat pada pencapaian Prestasi Belajar Akuntansi yang optimal. Berdasarkan hasil observasi dan wawancara terhadap siswa kelas XII IPS 3 pada hari Senin tanggal 26 November 2018, ketika jam pelajaran kosong siswa memilih untuk berbicara dengan teman sebayanya, mengantuk, dan pergi ke kantin dibandingkan mengisi jam pelajaran kosong dengan belajar materi akuntansi. Beberapa siswa juga tidak memperhatikan penjelasan materi akuntansi yang diberikan oleh guru, karena sibuk berbicara dengan teman di sebelah kanan atau kirinya, sehingga menyebabkan siswa tersebut dapat tertinggal materi akuntansi yang disampaikan oleh guru. Hal ini akan berdampak pada Prestasi Belajar Akuntansi siswa tersebut.

Faktor eksternal lain yang dapat mempengaruhi Prestasi Belajar Akuntansi adalah Lingkungan Keluarga. Lingkungan Keluarga merupakan lingkungan yang berperan dalam perkembangan anak. Menurut Hasbullah (2012: 38)
"Lingkungan Keluarga adalah lingkungan pendidikan anak yang pertama dan utama karena di dalam keluarga inilah anak pertama dan utama mendapatkan pendidikan dan bimbingan". Anak lebih banyak menghabiskan waktu dan mendapatkan pendidikan pada Lingkungan Keluarga. Lingkungan Keluarga yang baik akan mendorong dan memberikan semangat bagi setiap anak untuk berprestasi, dan sebaliknya Lingkungan Keluarga yang tidak baik akan membuat prestasi belajar anak menurun. Berdasarkan wawancara yang dilakukan peneliti dengan beberapa siswa kelas XII SMA Negeri 1 Sewon diketahui bahwa terdapat 3,74\% dari 107 siswa tinggal atau berada jauh dari Lingkungan Keluarganya. Hal ini menunjukkan bahwa siswa kurang atau tidak mendapatkan pengawasan terhadap kegiatan belajarnya. Anak akan kurang baik dalam mengatur waktunya antara belajar dan bermain di rumah. Hal ini akan berdampak pada Prestasi Belajar Akuntansi.

Faktor eksternal yang dapat mempengaruhi Prestasi Belajar lainnya adalah Metode Mengajar Guru. Metode Mengajar Guru merupakan faktor yang dapat mempengaruhi prestasi belajar siswa, di mana guru dituntut untuk menggunakan metode mengajar yang bervariasi dan menyenangkan sehingga tujuan pembelajaran akan tercapai. Berdasarkan observasi yang dilakukan pada kelas XII IPS 3 SMA Negeri 1 Sewon pada 26 November 2018 dapat diketahui bahwa guru masih menggunakan metode yang dominan dengan metode ceramah. Menurut Wina Sanjaya (2006: 147) "Metode Ceramah dapat diartikan sebagai cara menyajikan pelajaran melalui penuturan secara lisan atau penjelasan langsung kepada sekelompok siswa". Penggunaan metode ceramah tersebut menyebabkan terdapat persepsi siswa yang kurang baik. Hal ini terlihat ketika guru menjelaskan materi Akuntansi di depan kelas siswa kurang bersemangat dan tidak 
aktif dalam mengikuti proses belajar mengajar di kelas.

Selain ketiga faktor eksternal tersebut Prestasi Belajar Akuntansi juga dipengaruhi oleh Motivasi Belajar. Motivasi merupakan suatu dorongan yang berasal dari dalam maupun luar diri seseorang yang timbul untuk melakukan suatu kegiatan demi mencapai tujuan. Motivasi Belajar merupakan salah satu faktor penentu mengenai efektif tidaknya kegiatan belajar. Motivasi Belajar yang tinggi akan menyebabkan siswa cenderung memiliki dorongan untuk melakukan kegiatan belajar yang baik dengan demikian tujuan yang diharapkan akan tercapai seperti Prestasi Belajar Akuntansi yang tinggi. Berdasarkan observasi yang dilakukan peneliti di kelas XII IPS 3 sejumlah 25 siswa diketahui bahwa terdapat $12 \%$ siswa yang bermain HP dan $12 \%$ siswa yang tidur pada saat penyampaian materi serta siswa tidak tekun dalam menghadapi tugas yang diberikan oleh guru. Hal ini dikarenakan kurangnya Motivasi Belajar yang dimiliki oleh siswa, sehingga berdampak pada kurang optimalnya Prestasi Belajar Akuntansi.

Berdasarkan latar belakang masalah di atas, peneliti ingin mengetahui pengaruh Lingkungan Teman Sebaya, Lingkungan Keluarga, dan Motivasi Belajar terhadap Prestasi Belajar Akuntansi Siswa Kelas XII IPS SMA Negeri 1 Sewon Tahun Ajaran 2018/2019. Berdasarkan pengamatan, peneliti tertarik untuk meneliti masalah ini ke dalam skripsi yang berjudul "Pengaruh Lingkungan Teman Sebaya, Lingkungan Keluarga, dan Motivasi Belajar Terhadap Prestasi Belajar Akuntansi Siswa Kelas XII SMA N 1 Sewon Tahun Ajaran 2018/2019”.

\section{METODE PENELITIAN}

\section{Desain Penelitian}

Penelitian ini merupakan penelitian ex post facto karena penelitian ini berfokus meneliti tentang variabel yang kejadiannya sudah terjadi sebelum penelitian dilaksanakan (Suharsimi Arikunto, 2013: 17). Pendekatan yang digunakan adalah kuantitatif, di mana informasi atau data yang diperoleh dalam bentuk angka dan hasil penelitian ini berwujud data kuantitatif yang dianalisis dengan teknik statistik. Desain penelitian ini merupakan penelitian kausal komparatif karena penelitian ini dimaksudkan untuk mengetahui sebab akibat pengaruh Lingkungan Teman Sebaya, Lingkungan Keluarga, dan Motivasi Belajar terhadap Prestasi Belajar Akuntansi.

\section{Tempat dan Waktu Penelitian}

Penelitian ini dilaksanakan di SMA Negeri 1 Sewon yang beralamat di Jalan Parangtritis km 5, Bangunharjo, Sewon, Bantul, Yogyakarta. Penelitian ini dilaksanakan pada kelas XII IPS tahun ajaran 2018/2019. Pelaksanaan penelitian pada bulan Januari 2019-Maret 2019.

\section{Populasi dan Sampel Penelitian}

Populasi dalam penelitian ini adalah seluruh siswa Kelas XII IPS SMA Negeri 1 Sewon Tahun Ajaran 2018/2019 yang terdiri dari 4 kelas dalam jumlah 107 siswa.

Tabel 1. Jumlah Populasi Penelitian

\begin{tabular}{|c|c|c|}
\hline No & Kelas & Jumlah \\
\hline 1 & XII IPS 1 & 27 \\
\hline 2 & XII IPS 2 & 30 \\
\hline 3 & XII IPS 3 & 25 \\
\hline 4 & XII IPS 4 & 25 \\
\hline & Jumlah & 107 \\
\hline
\end{tabular}

Teknik pengambilan sampel dalam penelitian ini adalah dengan menggunakan teknik Simple Random Saampling yang artinya setiap subyek memiliki hak yang sama untuk menjadi sampel dalam penelitian dengan diambil secara acak oleh peneliti. Penentuan jumlah sampel dari populasi dalam penelitian ini berdasarkan tabel yang dikembangkan oleh Isaac dan Michael untuk tingkat kesalahan $5 \%$. 
Berdasarkan tabel tersebut penentuan jumlah sampel dengan jumlah populasi 107 siswa dengan taraf kesalahan 5\% maka diperoleh jumlah sampel yang digunakan adalah 83 siswa.

Tabel 2. Daftar Distribusi Sampel

\begin{tabular}{|c|c|c|}
\hline No & Kelas & Jumlah \\
\hline 1 & XII IPS 1 & 21 \\
\hline 2 & XII IPS 2 & 24 \\
\hline 3 & XII IPS 3 & 19 \\
\hline 4 & XII IPS 4 & 19 \\
\hline & Jumlah & 83 \\
\hline
\end{tabular}

\section{Teknik Pengumpulan Data}

Teknik pengumpulan data yang digunakan dalam penelitian ini adalah kuesioner (angket) dan dokumentasi. Suharsimi Arikunto (2013: 274) mengatakan bahwa "Dokumentasi merupakan cara pengumpulan data mengenai hal-hal atau variabel berupa catatan, transkip, buku, surat kabar, agenda, dan lain sebagainya". Data yang diperoleh menggunakan metode dokumentasi ini adalah data Prestasi Belajar Akuntansi yang dilihat dari ratarata total Nilai Ulangan Harian (UH), Penilaian Tengah Semester (PTS), Penilaian Akhir Semester (PAS) siswa kelas XII IPS SMA Negeri 1 Sewon Tahun Ajaran 2018/2019 pada aspek kognitif yang dimiliki oleh guru. Kuesioner merupakan teknik pengumpulan data yang dilakukan dengan memberi seperangkat pertanyaan atau pernyataan tertulis kepada responden untuk dijawabnya (Sugiyono, 2011: 142). Peneliti dalan penelitian ini menggunakan angket tertutup dan pengambilan data dilaksanakan secara langsung kepada responden. Kuesioner (angket) ini digunakan untuk mengukur variabel bebas yaitu, Lingkungan Teman Sebaya, Lingkungan Keluarga, dan Motivasi Belajar.

\section{Instrumen Penelitian}

Menurut Sugiyono (2011: 102) "Instrumen penelitian adalah suatu alat yang digunakan mengukur fenomena alam maupun sosial yang diamati". Instrumen penelitian ini yaitu menggunakan lembar angket. Pengembangan instrumen ini mengambil dari kerangka teori yang disusun yang selanjutnya dijabarkan ke dalam indikator. Penetapan skor pada instrumen angket ini menggunakan skala Likert yang dimodifikasi dengan memberikan skor 1 sampai dengan 4 pada setiap butir pernyataan yang diberikan. Responden disediakan 4 pilihan jawaban agar dapat melilih secara tegas jawaban dari pernyataan tersebut. Skor untuk setiap pernyataan positif (+) adalah 4-1, sedangkan skor untuk setiap pernyataan negatif 1-4.

Tabel 3. Skor Alternatif Jawaban

\begin{tabular}{|l|c|c|}
\hline \multirow{2}{*}{$\begin{array}{c}\text { Alternatif } \\
\text { Jawaban }\end{array}$} & \multicolumn{2}{c|}{$\begin{array}{c}\text { Skor untuk } \\
\text { pernyataan }\end{array}$} \\
\cline { 2 - 3 } & Positif & Negatif \\
\hline Sangat Setuju (SS) & 4 & 1 \\
\hline Setuju (S) & 3 & 2 \\
\hline Tidak Setuju (TS) & 2 & 3 \\
\hline $\begin{array}{l}\text { Sangat Tidak } \\
\text { Setuju (STS) }\end{array}$ & 1 & 4 \\
\hline
\end{tabular}

\section{Uji Coba Insrumen}

Sebelum instrumen digunakan dalam penelitian, maka instrumen harus diuji cobakan terlebih dahulu. Hal ini bertujuan agar mendapatkan informasi bahwa instrumen tersebut telah memenuhi syarat sebagai alat pengumpulan data yaitu valid dan reliabel. Pengujian imstrumen dilaksanakan di SMA Negeri 1 Seyegan yang dianggap memiliki karakteristik yang sama dengan SMA Negeri 1 Sewon. Uji coba dilakukan kepada 30 siswa kelas XII IPS SMA Negeri 1 Seyegan Tahun Ajaran 2018/2019. Menurut Suharsimi Arikunto (2013: 235) dalam melakukan uji coba instrumen analisis subjek uji coba dapat diambil sejumlah 25-40 orang. Hasil data uji coba instrumen selanjutnya adalah 
menggunakan alat bantu statistik untuk mengetahui tingkat validitas dan reliabilitas. Uji validitas digunakan untuk mengetahui valid atau tidaknya suatu instrumen, dengan teknik korelasi product moment dari Karl Pearson. Uji reliabilitas pada penelitian ini menggunakan rumus Alpha Cronbach.

\section{Teknik Analisis Data}

a. Uji Prasyarat Analisis

Uji prasyarat analisis yang digunakan sebelum melakukan pengujian hipotesis dalam penelitian ini terdiri dari uji normalitas, uji linearitas, dan uji multikolinearitas.

1) Uji Normalitas

Uji Normalitas bertujuan untuk mengetahui data yang diperoleh dari masing-masing variabel berdistribusi normal atau tidak, yaitu dengan cara pengujian menggunakan non parametric testOne Sample Kolmogrov Smirnov Test terhadap model regresi dengan menggunakan bantuan aplikasi Statistic.

2) Uji Linearitas

Uji linearitas digunakan untuk mengetahui pengaruh masingmasing variabel bebas mempunyai hubungan linear atau tidak terhadap variabel terikat. Hubungan antara variabel bebas terhadap variabel terikat dikatakan linear apabila $F_{\text {hitung }}<F_{\text {tabel. }}$ Sebaliknya, jika $\mathrm{F}_{\text {hitung }}>\mathrm{F}_{\text {tabel }}$ maka data dikatakan tidak linear pada taraf signifikansi $5 \%$.

3) Uji Multikolinearitas

Uji multikolinearitas digunakan untuk mengetahui ada tidaknya multikolinearitas antar variabel bebas. Ada tidaknya multikolinieritas dapat dilihat dengan nilai tTolerance $(\alpha)$ dan nilai variance inflation factor (VIF). Variabel bebas mengalami multikolinieritas jika $\alpha$ hitung $<\alpha$ dan VIF hitung > VIF. Sebaliknya variabel bebas tidak mengalami multikolinieritas jika $\alpha$ hitung $<\alpha$ dan VIF hitung < VIF, (Danang Sunyoto, 2007: 90).

b. Uji Hipotesis

Uji hipotesis dalam penelitian ini menggunakan analisis regresi sederhana dan analisis regresi ganda. Analisis regresi sederhana digunakan untuk pengujian hipotesis pertama yaitu terdapat pengaruh positif Lingkungan Teman Sebaya terhadap Prestasi Belajar Akuntansi Siswa Kelas XII IPS SMA Negeri 1 Sewon Tahun Ajaran 2018/2019, hipotesis kedua yaitu terdapat pengaruh positif Lingkungan Keluarga terhadap Prestasi Belajar Akuntansi Siswa Kelas XII IPS SMA Negeri 1 Sewon Tahun Ajaran 2018/2019, dan hipotesis ketiga yaitu terdapat pengaruh positif Motivasi Belajar terhadap Prestasi Belajar Akuntansi Siswa Kelas XII IPS SMA Negeri 1 Sewon Tahun Ajaran 2018/2019. Analisis regresi ganda digunakan untuk pengujian hipotesis keempat, yaitu terdapat pengaruh positif Lingkungan Teman Sebaya, Lingkungan Keluarga, dan Motivasi Belajar secara bersama-sama terhadap Prestasi Belajar Akuntansi Siswa Kelas XII IPS SMA Negeri 1 Sewon Tahun Ajaran 2018/2019.

\section{HASIL PENELITIAN DAN PEMBAHASAN \\ Uji Prasyarat Analisis}

a. Uji Normalitas

Hasil uji normalitas dengan bantuan program statistik, sebagai berikut. 


\section{Tabel 4. Ringkasan Hasil Uji Normalitas}

\begin{tabular}{|c|c|c|c|}
\hline N & Sign.hitung & Sign. & Ket \\
\hline 83 & 0,200 & 0,05 & Normal \\
\hline
\end{tabular}

Berdasarkan Tabel 4 tersebut dapat diketahui Sign $_{\text {hitung }}>$ Sign sehingga dapat disimpulkan bahwa data berdistribusi normal.

b. Uji Linearitas

Hasil uji linearitas dengan bantuan program statistik, sebagai berikut:

Tabel 5. Ringkasan Hasil Uji Linearitas

\begin{tabular}{|c|c|c|c|}
\hline Variabel & Fhitung & F tbael & Keterangan \\
\hline $\mathrm{X}_{1}-\mathrm{Y}$ & 1,066 & 1,703 & Linear \\
\hline $\mathrm{X}_{2}-\mathrm{Y}$ & 0,77 & 1,683 & Linear \\
\hline $\mathrm{X}_{3}-\mathrm{Y}$ & 0,614 & 1,698 & Linear \\
\hline
\end{tabular}

Berdasarkan Tabel 5 tersebut dapat diketahui bahwa harga $F_{\text {hitung }}$ dari perhitungan masing-masing variabel lebih kecil dari $F_{\text {tabel }}$ pada taraf signifikansi 5\%, sehingga semua pola hubungan variabel bebas dengan variabel terikat bersifat linear. c. Uji Multikolinearitas

Hasil uji multikolinearitas dengan bantuan program statistik, sebagai berikut:

Tabel 6. Ringkasan Hasil Uji Multikolinearitas

\begin{tabular}{|c|c|c|}
\hline Variabel & Tolerance & $\mathrm{VIF}$ \\
\hline $\mathrm{X}_{1}$ & 0,309 & 3,236 \\
\hline $\mathrm{X}_{2}$ & 0,468 & 2,137 \\
\hline $\mathrm{X}_{3}$ & 0,432 & 2,315 \\
\hline
\end{tabular}

Berdasarkan Tabel 6 tersebut, dapat diketahui bahwa ketiga variabel bebas tidak terjadi multikolinearitas karena nilai $\mathrm{VIF}_{\text {hitung }}<\mathrm{VIF}$ (!)), dan semua tolerance variabel bebas lebih besar dari $10 \%$.

\section{Uji Hipotesis}

a. Uji Hipotesis Pertama

Hasil uji analisis regresi sederhana hipotesis pertama dapat dilihat pada tabel sebagai berikut:

Tabel 7. Ringkasan Hasil Uji Hipotesis Pertama $\left(\mathrm{X}_{1}-\mathrm{Y}\right)$

\begin{tabular}{|c|c|c|c|c|c|c|}
\hline \multicolumn{2}{|c|}{ Harga $\mathbf{r}-\mathbf{r}^{\mathbf{2}}$} & $\mathbf{t}_{\text {hit }}$ & $\mathbf{t}_{\text {tab }}$ & koef & Konstanta & Sig \\
\hline $\mathbf{r}_{\mathbf{x} 1 \mathbf{y}}$ & $\mathbf{r}^{\mathbf{2}} \mathbf{x 1 y}$ & & & & & \\
\hline 0,423 & 0,179 & 4,200 & 1,664 & 0,648 & 24,221 & 0,000 \\
\hline
\end{tabular}

Berdasarkan Tabel 7 tersebut, daoat diketahui bahwa koefisien korelasi $\mathrm{X}_{1}$ terhadap $\mathrm{Y}$ menunjukkan nilai $r_{x 1 y}$ sebesar 0,423 . Koefisien korelasi tersebut bernilai positif sehingga dapat disimpulkan bahwa Lingkungan Teman Sebaya memiliki hubungan yang positif dengan Prestasi Belajar Akuntansi. Koefisien determinasi $\mathrm{X}_{1}$ terhadap $\mathrm{Y} \quad\left(\mathrm{r}_{\mathrm{x} 1 \mathrm{y}}^{2}\right)$ sebesar 0,179. Nilai tersebut menunjukkan bahwa Lingkungan Teman Sebaya mempengaruhi Prestasi Belajar Akuntansi sebesar 17,9\%. Hal ini menunjukkan bahwa $82,1 \%$ Prestasi Belajar Akuntansi dipengaruhi oleh faktor atau variabel lain. Besarnya koefisien Lingkungan Teman Sebaya $\left(\mathrm{X}_{1}\right)$ sebesar 0,648 dan bilangan konstanta sebesar 24,221 maka persamaan garis regresi dinyatakan dalam persamaan $\mathrm{Y}=$ $24,221+0,648 X_{1}$. Persamaan tersebut menunjukkan bahwa nilai koefisien $\mathrm{X}_{1}$ sebesar 0,648 yang berarti apabila nilai Lingkungan Teman Sebaya $\left(\mathrm{X}_{1}\right)$ meningkat 1 satuan maka nilai Prestasi Belajar Akuntansi (Y) akan meningkat sebesar 0,648 satuan. Hasil uji $\mathrm{t}$ dengan uji satu fihak dan taraf signifikansi $5 \%$ diperoleh thitung sebesar 4,200 lebih besar dari $t_{\text {tabel }}$ 1,664, sehingga dapat disimpulkan bahwa terdapat pengaruh positif dan signifikan Lingkungan Teman Sebaya $\left(\mathrm{X}_{1}\right)$ terhadap Prestasi Belajar Akuntansi (Y) Siswa Kelas XII IPS 
SMA Negeri 1 Sewon Tahun Ajaran 2018/2019.

b. Uji Hipotesis Kedua
Hasil analisis regresi sederhana hipotesis kedua dapat dilihat pada tabel sebagai berikut:

Tabel 8. Ringkasan Hasil Uji Hipoetsis Kedua ( $\left.\mathrm{X}_{2}-\mathrm{Y}\right)$

\begin{tabular}{|c|c|c|c|c|c|c|}
\hline \multicolumn{2}{|c|}{ Harga $\mathbf{r}^{-\mathbf{r}^{2}}$} & $\mathbf{t}_{\text {hit }}$ & $\mathbf{t}_{\text {tab }}$ & koef & Konstanta & Sig \\
\hline $\mathrm{r}_{\mathrm{x} 2 \mathrm{y}}$ & $\mathrm{r}_{\mathrm{x} 2 \mathrm{y}}$ & & & & & \\
\hline 0,354 & 0,125 & 3,406 & 1,664 & 0,356 & 34,789 & 0,001 \\
\hline
\end{tabular}

Berdasarkan Tabel 8 dapat diketahui bahwa koefisien korelasi $\left(\mathrm{r}_{\mathrm{x} 2 \mathrm{y}}\right)$ sebesar 0,354 . Koefisien korelasi tersebut bernilai positif sehingga dapat disimpulkan bahwa Lingkungan Keluarga memiliki hubungan yang positif dengan Prestasi Belajar Akuntansi. Koefisien determinasi $\mathrm{X}_{2}$ terhadap $\mathrm{Y}\left(\mathrm{r}_{\mathrm{x} 2 \mathrm{y}}\right)$ sebesar 0,125 . Nilai tersebut menunjukkan bahwa Lingkungan Keluarga mempengaruhi Prestasi Belajar Akuntansi sebesar 12,5\%. Hal ini menunjukkan bahwa 87,5\% Prestasi Belajar Akuntansi dipengaruhi oleh faktor atau variabel lain. Besarnya koefisien Lingkungan Keluarga $\left(\mathrm{X}_{2}\right)$ sebesar 0,356 dan bilangan konstanta sebesar 34,789 maka persamaan garis regresi dinyatakan dalam persamaan $\mathrm{Y}=$ $34,789+0,356 \mathrm{X}_{1}$. Persamaan tersebut menunjukkan bahwa nilai koefisien $\mathrm{X}_{2}$ sebesar 0,356 yang berarti apabila nilai Lingkungan Keluarga $\left(\mathrm{X}_{2}\right)$ meningkat 1 satuan maka nilai Prestasi Belajar Akuntansi (Y) akan meningkat sebesar 0,356 satuan. Hasil uji t dengan uji satu fihak dan taraf signifikansi $5 \%$ diperoleh $t_{\text {hitung }}$ sebesar 3,406 lebih besar dari $t_{\text {tabel }} 1,664$, sehingga dapat disimpulkan bahwa terdapat pengaruh positif dan signifikan antara Lingkungan Keluarga $\left(\mathrm{X}_{2}\right)$ terhadap Prestasi Belajar Akuntansi (Y) Siswa Kelas XII IPS SMA Negeri 1 Sewon Tahun Ajaran 2018/2019.

c. Uji Hipotesis Ketiga

Hasil analisis regresi sederhana hipotesis ketiga dapat dilihat pada tabel sebagai berikut:

Tabel 9. Ringkasan Hasil Uji Hipotesis Ketiga (X3-Y)

\begin{tabular}{|c|c|c|c|c|c|c|}
\hline \multicolumn{2}{|c|}{ Harga $\mathbf{r}^{-\mathbf{r}^{2}}$} & $\mathbf{t}_{\text {hit }}$ & $\mathbf{t}_{\text {tab }}$ & koef & Konstanta & Sig \\
\hline $\mathbf{r}_{\mathbf{x} 3 \mathbf{y}}$ & $\mathbf{r}^{\mathbf{2}} \mathbf{3 \mathbf { y }}$ & & & & & \\
\hline 0,369 & 0,157 & 3,884 & 1,664 & 0,462 & 26,700 & 0,00 \\
\hline
\end{tabular}

Berdasarkan Tabel 9 dapat diketahui bahwa koefisien korelasi $\left(\mathrm{r}_{x 3 \mathrm{y}}\right)$ sebesar 0,369. Koefisien korelasi tersebut bernilai positif sehingga dapat disimpulkan bahwa Motivasi Belajar memiliki hubungan yang positif dengan Prestasi Belajar Akuntansi. Koefisien determinasi $\mathrm{X}_{3}$ terhadap $\mathrm{Y}$ $\left(r^{2} \times 3 y\right)$ sebesar 0,157. Nilai tersebut menunjukkan bahwa Motivasi Belajar mempengaruhi Prestasi Belajar Akuntansi sebesar $15,7 \%$. Hal ini menunjukkan bahwa 84,3\% Prestasi Belajar Akuntansi dipengaruhi oleh faktor atau variabel lain. Besarnya koefisien Motivasi Belajar $\left(\mathrm{X}_{3}\right)$ sebesar 0,462 dan bilangan konstanta sebesar 26,700, maka persamaan garis regresi dinyatakan dalam persamaan $\mathrm{Y}$ $=26,700+0,462 X_{3}$. Persamaan 
tersebut menunjukkan bahwa nilai koefisien $\mathrm{X}_{3}$ sebesar 0,462 yang berarti apabila nilai Motivasi Belajar $\left(\mathrm{X}_{3}\right)$ meningkat 1 satuan maka nilai Prestasi Belajar Akuntansi (Y) akan meningkat sebesar 0,462 satuan. Hasil uji t dengan uji satu fihak dan taraf signifikansi $5 \%$ diperoleh thitung sebesar 3,884 lebih besar dari tabel 1,664, sehingga dapat disimpulkan bahwa terdapat pengaruh positif dan signifikan antara Motivasi Belajar $\left(\mathrm{X}_{3}\right)$ terhadap Prestasi Belajar Akuntansi (Y) Siswa Kelas XII IPS SMA Negeri 1 Sewon Tahun Ajaran 2018/2019.

d. Uji Hipotesis Keempat

Hasil analisis regresi ganda hipotesis keempat dapat dilihat pada tabel sebagai berikut:

Tabel 10. Ringkasan Hasil Uji Hipotesis Keempat $\left(X_{1}, X_{2}, X_{3}-Y\right)$

\begin{tabular}{|c|c|c|c|c|c|c|}
\hline \multicolumn{2}{|c|}{ Harga R-R } & F $_{\text {hit }}$ & $\mathbf{F}_{\text {tab }}$ & Koef & Konstanta & Sig \\
\hline $\mathbf{R}_{\mathbf{y}(\mathbf{1}, \mathbf{2 , 3})}$ & $\mathbf{R}_{\mathbf{y} \mathbf{9 1 , 2 , 3 )}}$ & & & & & \\
\hline 0,443 & 0,196 & 6,432 & 2,720 & 0,355 & 18,527 & 0,001 \\
\hline
\end{tabular}

Berdasarkan Tabel 10 dapat diketahui bahwa koefisien korelasi $\left(\mathrm{R}_{\mathrm{y}(1,2,3)}\right)$ sebesar 0,443. Koefisien korelasi tersebut bernilai positif sehingga dapat disimpulkan bahwa Lingkungan Teman Sebaya, Lingkungan Keluarga, dan Motivasi Belajar secara bersama-sama memiliki hubungan yang positif terhadap Prestasi Belajar Akuntansi. Koefisien determinasi $\mathrm{X} 1, \mathrm{X}_{2}$, dan $\mathrm{X}_{3}$ terhadap $\mathrm{Y}$ $\left(\mathrm{R}_{\mathrm{y}(1,2,3)}^{2}\right)$ sebesar 0,196 196 yang berarti bahwa Lingkungan Teman Sebaya, Lingkungan Keluarga, dan Motivasi Belajar secara bersama-sama mempengaruhi Prestasi Belajar Akuntansi sebesar 19,6\%. Hal ini menunjukkan bahwa $80,4 \%$ Prestasi Belajar Akuntansi dipengaruhi oleh faktor atau variabel lain. Besarnya koefisien Lingkungan Teman Sebaya $\left(\mathrm{X}_{1}\right) \quad$ sebesar 0,355, koefisien Lingkungan Keluarga $\left(X_{2}\right)$ sebesar 0,085, koefisien Motivasi Belajar $\left(\mathrm{X}_{3}\right)$ sebesar 0,201, dan bilangan konstanta sebesar 18,527, maka persamaan garis regresi dinyatakan dalam persamaan $\mathrm{Y}$ $=18,527+0,355 \mathrm{X}_{1}+0,085 \mathrm{X}_{2}+$ $0,201 \quad X_{3}$. Persamaan tersebut menunjukkan bahwa nilai koefisien Lingkungan Teman Sebaya $\left(\mathrm{X}_{1}\right)$ sebesar 0,355 artinya apabila $\mathrm{X}_{1}$ meningkat 1 satuan maka Prestasi Belajar Akuntansi (Y) akan meningkat dengan asumsi $\mathrm{X}_{2}$ dan $\mathrm{X}_{3}$ tetap. Nilai koefisien Lingkungan Keluarga $\left(\mathrm{X}_{2}\right)$ sebesar 0,085 artinya apabila $\mathrm{X}_{2}$ meningkat 1 satuan maka Prestasi Belajar Akuntansi (Y) akan meningkat 0,085 dengan asumsi $\mathrm{X}_{1}$ dan $\mathrm{X}_{3}$ tetap. Nilai koefisien Motivasi Belajar $\left(\mathrm{X}_{3}\right)$ sebesar 0,201 artinya apabila $\mathrm{X}_{3}$ meningkat 1 satuan maka Prestasi Belajar Akuntansi (Y) akan meningkat sebesar 0,201 dengan asumsi $\mathrm{X}_{1}$ dan $\mathrm{X}_{2}$ tetap. Nilai F Fitung sebesar 6,432lebih besar dibandingkan dengan $F_{\text {tabel }}$ sebesar 2,720, sehingga dapat disimpulkan bahwa terdapat pengaruh positif dan signifikan Lingkungan Teman Sebaya $\left(\mathrm{X}_{1}\right)$, Lingkungan Keluarga $\left(\mathrm{X}_{2}\right)$, dan Motivasi Belajar $\left(\mathrm{X}_{3}\right)$ secara bersama-sama terhadap Prestasi Belajar Akuntansi (Y) pada Siswa Kelas XII IPS SMA Negeri 1 Sewon Tahun Ajaran 2018/2019.

e. Sumbangan Relatif dan Sumbangan Efektif

Berdasarkan hasil analisis regresi gandam dapat diketahui besarnya Sumbangan Relatif dan Sumbangan Efektif masing-masing variabel bebas (Lingkungan Teman Sebaya, 
Lingkungan Keluarga, dan Motivasi Belajar) sebagai berikut:

Tabel 11. Hasil Sumbangan Relatif dan Sumbangan Efektif

\begin{tabular}{|c|c|c|c|}
\hline \multirow{2}{*}{ No } & \multirow{2}{*}{ Variabel } & \multicolumn{2}{|c|}{ Sumbangan } \\
\hline & & Relatif & Efektif \\
\hline 1 & $\begin{array}{l}\text { Lingkungan } \\
\text { Teman } \\
\text { Sebaya }\end{array}$ & $48,23 \%$ & $9,45 \%$ \\
\hline 2 & $\begin{array}{l}\text { Lingkungan } \\
\text { Keluarga }\end{array}$ & $15,71 \%$ & $3,08 \%$ \\
\hline 3 & $\begin{array}{l}\text { Motivasi } \\
\text { Belajar }\end{array}$ & $36,06 \%$ & $7,07 \%$ \\
\hline & Total & $100 \%$ & $19,6 \%$ \\
\hline
\end{tabular}

Berdasarkan Tabel 11 dapat diketahui Sumbangan Relatif untuk variabel Lingkungan Teman Sebaya terhadap Prestasi Belajar Akuntansi sebesar 48,23\%, variabel Lingkungan Keluarga terhadap Prestasi Belajar Akuntansi sebesar 15,71\%, dan variabel Motivasi Belajar terhadap Prestasi Belajar Akuntansi sebesar $36,06 \%$. Sumbangan efektif dari variabel Lingkungan Teman Sebaya sebesar 9,45\%, Lingkungan Keluarga sebesar 3,08\%, dan Motivasi Belajar sebesar 7,07\%. Sumbangan efektif total sebesar $19,6 \%$ yang berarti secara bersama-sama variabel Lingkungan Teman Sebaya, Lingkungan Keluarga, dan Motivasi Belajar memberikan sumbangan efektif sebesar 19,6\% terhadap Prestasi Belajar Akuntansi, sedangkan sebesar 80,4\% diberikan oleh variabel-variabel lain yang tidak dibahas pada penelitian ini.

\section{Pembahasan}

a. Pengaruh Lingkungan Teman Sebaya terhadap Prestasi Belajar Akuntansi Siswa Kelas XII IPS SMA Negeri 1 Sewon Tahun Ajaran 2018/2019
Hasil penelitian ini menunjukkan adanya pengaruh positif dan signifikan Lingkungan Teman Sebaya terhadap Prestasi Belajar Akuntansi yang ditunjukkan dengan nilai $r_{x 1 y}(0,423)$, $r^{2}{ }_{x 1 y}(0,179)$ dan $t_{\text {hitung }}(4,200)>t_{\text {tabel }}$ $(1,664)$. Hasil ini sesuai dengan kerangka berpikir yaitu Lingkungan Teman Sebaya yang baik akan meningkatkan Prestasi Belajar Akuntansinya. Hasil ini selaras dengan pendapat dari Muhibbin Syah (2010: 137) yang menyatakan bahwa salah satu faktor eksternal yang mempengaruhi Prestasi Belajar Akuntansi adalah Lingkungan Teman Sebaya. Lingkungan Teman Sebaya adalah lingkungan di sekitar siswa yang memiliki kesamaan usia, pemikiran, hobi, status, dan keadaan yang sama di sekolah yang saling berinteraksi sehingga dapat berpengaruh positif maupun negatif bagi perilaku siswa. Siswa yang berada pada Lingkungan Teman Sebaya yang baik, maka dipastikan siswa tersebut akan semangat guna mendapatkan Prestasi Belajar Akuntansi yang tinggi. Begitu juga sebaliknya apabila siswa tersebut berada di Lingkungan Teman Sebaya yang kurang baik, maka menyebabkan siswa tersebut untuk bermalas-malasan dan enggan untuk belajar sehingga berdampak pada rendahnya Prestasi Belajar Akuntansi.

Hal ini sejalan dengan penelitian oleh Nur Hanifah (2015) yang berjudul "Pengaruh Minat Belajar, Lingkungan Teman Sebaya, dan Persepsi Siswa tentang Metode Mengajar Guru terhadap Prestasi Belajar Pengantar Akuntansi Keuangan Siswa Kelas X Keuangan SMK Negeri 1 Bantul Tahun Ajaran 2014/2015", dapat dilihat dari nilai koefisien regresi sebesar 0,315 . Pada taraf signifikansi 5\% dapat diketahui thitung sebesar 3,233 dengan nilai signifikansi 0,002 , karena koefisien regresi mempunyai nilai 
positif dan nilai signifikansi $<0,05$. Berdasarkan teori, penelitian terdahulu, dan penelitian yang telah peneliti lakukan maka dapat ditarik kesimpulan bahwa Lingkungan Teman Sebaya mempengaruhi Prestasi Belajar Akuntansi secara positif.

b. Pengaruh Lingkungan Teman Sebaya terhadap Prestasi Belajar Akuntansi Siswa Kelas XII IPS SMA Negeri 1 Sewon Tahun Ajaran 2018/2019

Hasil uji regresi sederhana Lingkungan Keluarga berpengaruh positif dan signifikan terhadap Prestasi Belajar Akuntansi Siswa Kelas XII IPS SMA Negeri 1 Sewon Tahun Ajaran 2018/2019 yang ditunjukkan dengan nilai $r_{\mathrm{x} 2 \mathrm{y}}(0,354), \mathrm{r}_{\mathrm{x} 2 \mathrm{y}}(0,125)$ dan $t_{\text {hitung }}(3,406)>t_{\text {tabel }}(1,664)$. Hasil ini selaras dengan kerangka berpikir yaitu Lingkungan Keluarga yang baik, nyaman, dan tenang bagi anak akan meningkatkan Prestasi Belajar Akuntansi. Lingkungan Keluarga adalah lingkungan pendidikan pertama yang menjadi dasar tingkah laku anak dalam tumbuh dan berkembang menjadi dewasa serta dapat mempengaruhi prestasi belajarnya.

Hasil penelitian ini juga diperkuat dengan teori. Menurut Slameto (2013: 54-71) prestasi belajar dapat dipengaruhi oleh dua faktor yaitu faktor intern dan faktor ekstern. Salah satu faktor ekstern yang dapat mempengaruhi prestasi belajar adalah Lingkungan Keluarga. Hasil penelitian ini diperkuat dengan penelitian yang dilakukan oleh Bebi Ratnasari (2017) yang berjudul "Pengaruh Motivasi Belajar, Kompetensi Guru, dan Lingkungan Keluarga terhadap Prestasi Belajar Akuntansi Perusahaan Dagang Siswa Kelas XI Akuntansi SMK YPKK 2 Sleman Tahun Ajaran 2016/2017', dibuktikan dengan $r_{x 3 y}=0,328, \quad r^{2}{ }_{x 3 y}=0,108, \quad$ dan $t_{\text {hitung }}$ $(3,692)>t_{\text {abel }} \quad(1,552)$. Berdasarkan teori, penelitian terdahulu, dan penelitian yang telah dilakukan peneliti maka dapat ditarik kesimpulan bahwa Lingkungan Keluarga mempengaruhi Prestasi Belajar Akuntansi secara positif.

c. Pengaruh Motivasi Belajar terhadap Prestasi Belajar Akuntansi Siswa Kelas XII IPS SMA Negeri 1 Sewon Tahun Ajaran 2018/2019

Hasil penelitian ini menunjukkan adanya pengaruh positif dan signifikan Motivasi Belajar terhadap Prestasi Belajar Akuntansi yang ditunjukkan dengan nilai $r_{x 3 y}(0,396), r_{x 3 y}^{2}(0,157)$ dan $t_{\text {hitung }}(3,884)>t_{\text {tabel }}(1,664)$. Hasil ini sesuai dengan kerangka berpikir yaitu Motivasi Belajar yang tinggi akan meningkatkan Prestasi Belajar Akuntansi.

Hasil ini selaras dengan pendapat dari Deni Febrini (2017: 86-98) yang menyatakan bahwa salah satu faktor eksternal yang mempengaruhi Prestasi Belajar Akuntansi adalah Motivasi Belajar. Siswa yang mampu meningkatkan Motivasi Belajar dengan optimal akan memperoleh Prestasi Belajar Akuntansi yang tinggi, sedangkan siswa yang memiliki Motivasi Belajar yang rendah akan memperoleh Prestasi Belajar Akuntansi yang rendah. Motivasi Belajar adalah dorongan internal dan eksternal pada diri siswa yang menimbulkan kegiatan belajar untuk mengadakan perubahan tingkah laku yang didasari oleh beberapa indikator atau faktor pendukung. Hal ini sejalan dengan penelitian oleh Muhammad Asri Saputra (2017) yang berjudul "Pengaruh Minat Belajar, Motivasi Belajar, dan Lingkungan Teman Sebaya terhadap Prestasi Belajar Akuntansi Siswa Kelas XI IPS SMA Negeri 1 Prambanan Klaten Tahun Ajaran 2016/2017", dapat dilihat dari nilai koefisien regresi 
sebesar 0,256. Berdasarkan teori, penelitian terdahulu, dan penelitian yang telah oeneliti lakukan maka dapat ditarik kesimpulan bahwa Motivasi Belajar mempengaruhi Prestasi Belajar Akuntansi secara positif.

d. Pengaruh Lingkungan Teman Sebaya, Lingkungan Keluarga, Motivasi Belajar secara bersama-sama terhadap Prestasi Belajar Akuntansi Siswa Kelas XII IPS SMA Negeri 1 Sewon Tahun Ajaran 2018/2019

Hasil penelitian setelah dilakukan analisis bersama-sama antara ketiga variabel bebas dengan satu variabel terikat, maka diperoleh pengaruh positif dan signifikan Lingkungan Teman Sebaya, Lingkungan Keluarga, dan Motivasi Belajar secara bersamasama terhadap Prestasi Belajar Akuntansi yang ditunjukkan dengan nilai $\mathrm{R}_{\mathrm{y}(1,2,3)}$ sebesar $0,443, \mathrm{R}_{\mathrm{y}(1,2,3)}$ sebesar 0,196, dan $F_{\text {hitung }}(6,432)>$ $F_{\text {tabel }}(2,72)$. Ini berarti nilai $R_{(1,2,3)}^{2}$ sebesar 0,196 menunjukkan 19,6\% Prestasi Belajar Akuntansi dipengaruhi oleh Lingkungan Teman Sebaya, Lingkungan Keluarga, dan Motivasi Belajar, sedangkan sisanya sebesar $80,4 \%$ dipengaruhi oleh faktor lain yang tidak dianalisis dalam penelitian ini.

Hasil ini sesuai dengan teori yang dikemukakan oleh Slameto (2013: 5471) bahwa prestasi belajar dipengaruhi oleh dua faktor yaitu faktor intern dan faktor ekstern. Faktor yang termasuk dalam faktor intern yaitu faktor jasmaniah (faktor kesehatan dan cacat tubuh), faktor psikologis (inteligensi, perhatian, minat, bakat, motif, kematangan, dan kelelahan), dan faktor kelelahan. Faktor yang termasuk dalam faktor ekstern yaitu faktor keluarga (cara orang tua mendidik, relasi antar anggota keluarga, suasana rumah, keadaan ekonomi keluarga, pengertian orang tua, dan latar belakang kebudayaan), faktor sekolah (metode mengajar, kurikulum, relasi guru dengan siswa, relasi siswa dengan siswa, disiplin sekolah, alat pelajaran, waktu sekolah standar pelajaran di atas ukuran, keadaan gedung, metode belajar, dan tugas rumah), dan faktor masyarakat (kegiatan siswa dalam masyarakat, mass media, teman bergaul, dan bentuk kehidupan masyarakat). Penelitian ini juga selaras dengan teori yang dikemukakan oleh Muhibbin Syah (2010: 137) bahwa prestasi belajar dipengaruhi oleh tiga faktor yaitu faktor internal, faktor eksternal, dan faktor pendekatan belajar. Berdasarkan teori, penelitian terdahulu, dan penelitian yang telah peneliti lakukan dapat disimpulkan bahwa Lingkungan Teman Sebaya, Lingkungan Keluarga, dan Motivasi Belajar secara bersama-sama mempengaruhi Prestasi Belajar Akuntansi secara positif

\section{SIMPULAN DAN SARAN Simpulan}

Berdasarkan pembahasan yang telah diuraikan sebelumnya, maka dapat ditarik kesimpulan, sebagai berikut:

a. Terdapat pengaruh positif dan signifikan Lingkungan Teman Sebaya terhadap Prestasi Belajar Akuntansi Siswa Kelas XII IPS SMA Negeri 1 Sewon Tahun Ajaran 2018/2019 yang ditunjukkan dengan nilai $\mathrm{r}_{\mathrm{x} 1 \mathrm{y}}(0,423)$, $\mathrm{r}_{\text {x1y }}^{2}(0,179), \mathrm{t}_{\text {hitung }}(4,200)>\mathrm{t}_{\text {tabel }}$ $(1,664)$ pada taraf signifikansi $5 \%$, dan garis regresi $\mathrm{Y}=24,221+0,648 \mathrm{X}_{1}$.

b. Terdapat pengaruh positif dan signifikan Lingkungan Keluarga terhadap Prestasi Belajar Akuntansi Siswa Kelas XII IPS SMA Negeri 1 Sewon Tahun Ajaran 2018/2019 yang ditunjukkan dengan nilai $r_{x 2 y}(0,354)$, $r_{x 2 y}^{2}(0,125), t_{\text {hitung }}(3,406)>t_{\text {tabel }}$ 
$(1,664)$ pada taraf signifikansi $5 \%$, dan garis regresi $\mathrm{Y}=34,789+0,356 \mathrm{X}_{2}$.

c. Terdapat pengaruh positif dan signifikan Motivasi Belajar terhadap Prestasi Belajar Akuntansi Siswa Kelas XII IPS SMA Negeri 1 Sewon Tahun Ajaran 2018/2019 yang ditunjukkan dengan nilai $r_{x 3 y}(0,396), r^{2} \times 3 y(0,157)$, thitung $(3,884)>t_{\text {tabel }}(1,664)$ pada taraf signifikansi $5 \%$, dan garis regresi $\mathrm{Y}=$ $26,700+0,462 X_{3}$

d. Terdapat pengaruh positif dan signifikan Lingkungan Teman Sebaya, Lingkungan Keluarga, dan Motivasi Belajar secara bersama-sama terhadap Prestasi Belajar Akuntansi Siswa Kelas XII IPS SMA Negeri 1 Sewon Tahun Ajaran 2018/2019 yang ditunjukkan dengan nilai $\mathrm{R}_{\mathbf{y}(1,2,3)}$ sebesar 0,443, $\mathrm{R}^{2} \mathrm{y}(1,2,3)$ sebesar 0,196 , F Fhitung $(6,432)>$ $\mathrm{F}_{\text {tabel }}(2,72)$, dan persamaan garis regresi: $\mathrm{Y}=18,527+0,355 \mathrm{X}_{1}+0,085$ $X_{2}+0,201 X_{3}$.

\section{Saran}

Berdasarkan kesimpulan yang telah diuraikan sebelumnya, peneliti dapat memberikan beberapa saran, sebagai berikut:

a. Bagi Sekolah

Berdasarkan hasil penelitian yang telah teruji variabel Lingkungan Teman Sebaya memiliki pengaruh positif dan signifikan terhadap Prestasi Belajar Akuntansi. Berdasarkan data yang diperoleh melalui pengisian angket pada pernyataan "Saya bersedia memberikan jawaban pekerjaan rumah materi akuntansi kepada teman saya agar tidak dianggap pelit" memiliki jumlah skor terendah. Oleh karena itu, lebih baik apabila guru dapat menanamkan dan memberikan penjelasan kepada siswa bahwa pekerjaan rumah yang diberikan merupakan tugas yang harus dikerjakan secara individu dan siswa harus mampu untuk bersaing secara sehat dalam mengerjakan tugas. b. Bagi Siswa

Berdasarkan hasil penelitian yang telah teruji variabel Lingkungan Keluarga memiliki pengaruh positif dan signifikan terhadap Prestasi Belajar Akuntansi. Berdasarkan data yang diperoleh melalui pengisian angket pada pernyataan "Saya dan saudara saya berdiskusi mengenai kesulitan belajar akuntansi yang dialami" memiliki jumlah skor terendah. Oleh karena itu, diharapkan siswa mampu berdiskusi dengan saudaranya mengenai kesulitan yang dialaminya, sehingga siswa tidak hanya belajar di sekolah saja namun di Lingkungan Keluarga siswa juga dapat belajar dengan berdiskusi dengan saudaranya.

Selain itu berdasarkan hasil penelitian yang telah teruji variabel Motivasi Belajar memiliki pengaruh positif dan signifikan terhadap Prestasi Belajar Akuntansi. Berdasarkan data yang diperoleh melalui pengisian angket pernyataan "Saya tidak suka apabila ada teman yang mencontek pekerjaan saya" memiliki jumlah skor terendah. Oleh karena itu, siswa seharusnya menyadari bahwa jika ada teman yang mencotek pekerjaannya itu akan merugikan siswa tersebut. Hal ini dikarenakan temannya akan ketergantungan dalam mengerjakan tugas maupun ujian dengan melihat pekerjaan siswa lainnya, dengan demikian siswa tersebut akan semakin malas untuk belajar. Apabila siswa tersebut tidak memperbolehkan temannya untuk mencotek pekerjaannya maka akan memacu teman atau siswa lain untuk giat belajar.

c. Bagi Penelitian selanjutnya

Penelitian ini memberikan informasi bahwa Lingkungan Teman Sebaya, Lingkungan Keluarga, dan Motivasi Belajar secara bersama-sama berpengaruh positif terhadap Prestasi 
Belajar Siswa Kelas XII IPS SMA Negeri 1 Sewon Tahun Ajaran 2018/2019. Sumbangan Efektif yang diperoleh dalam penelitian ini yaitu sebesar 19,6\%. Hasil ini menunjukkan bahwa Prestasi Belajar Akuntansi tidak hanya dipengaruhi oleh ketiga variabel yaitu Lingkungan Teman Sebaya, Lingkungan Keluarga, dan Motivasi Belajar. Oleh karena itu, diharapkan dalam penelitian selanjutnya dapat ditemukan variabelvariabel lain yang dapat mempengaruhi Prestasi Belajar Akuntansi.

\section{DAFTAR PUSTAKA}

Bebi Ratnasari. (2017). Pengaruh Motivasi Belajar, Kompetensi Guru, dan Lingkungan Keluarga terhadap Prestasi Belajar Akuntansi Perusahaan Dagang Siswa Kelas XI Akuntansi SMK YPKK 2 Sleman Tahun Ajaran 2016/2017. Skripsi. Universitas Negeri Yogyakarta.

Danang Sunyoto. (2007). Analisis Regresi dan Korelasi Bivariat Ringkasan dan Kasus. Yogyakarta: Amara Book.

Deni Febrini. (2017). Psikologi Pembelajaran. Yogyakarta: Pustaka Belajar.

Depdikbud. (2003). Undang-Undang RI Nomor 20, Tahun 2003, tentang Sistem Pendidikan Nasional

Direktorat Jenderal Peningkatan Mutu Pendidik dan Tenaga Kependidikan. (2008). Kriteria dan Indikator Keberhasilan Pembelajaran. Makalah disajikan dalam Diklat Peningkatan Kompetensi Pengawas Sekolah.

Hasbullah. (2012). Dasar-dasar Ilmu Pendidikan. Jakarta: PT RajaGrafindo Persada.
Muhammad Asri Saputra. (2017). Pengaruh Minat Belajar, Motivasi Belajar, dan Lingkungan Teman Sebaya terhadap Prestasi Belajar Akuntansi Siswa Kelas XI IPS SMA Negeri 1 Prambanan Klaten Tahun Ajaran 2016/2017. Skripsi. Universitas Negeri Yogyakarta.

Muhibbin Syah. (2010). Psikologi Pendididkan dengan Pendekatan Baru. Bandung: PT Remaja Rosdakarya.

Nur Hanifah. (2015). Pengaruh Minat Belajar, Lingkungan Teman Sebaya, dan Persepsi Siswa tentang Metode Mengajar Guru terhadap Prestasi Belajar Pengantar Akuntansi Keuangan Siswa Kelas X Keuangan SMK Negri 1 Bantul Tahun Ajaran 2014/2015. Skripsi. Universitas Negeri Yogyakarta.

Slameto. (2015). Belajar Dan FaktorFaktor Yang Mempengaruhinya. Jakarta: Rineka Cipta.

Sugihartono. (2015). Psikologi Pendidikan. Yogyakarta: UNY Press.

Sugiyono. (2011). Metode Penelitian Kuantitatif, Kualitatif, dan $R \& D$. Bandung: Alfabeta.

Suharsimi Arikunto. (2013). Prosedur Penelitian: Suatu Pendekatan Praktik. Jakarta: PT Rineka Cipta.

Wina Sanjaya. (2006). Strategi Pembelajaran Berorientasi Standar Proses Pendidikan. Jakarta: Kencana Prenadamedia Group. 